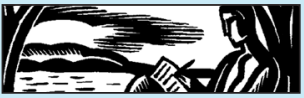

\title{
Sharing Small Stories of Life and Death Online: Death-writing of the Moment
}

\author{
Korina Giaxoglou
}

The Open University, UK

\section{ABSTRACT}

This article discusses public (and semi-public) reactions to death events attracting media and social media attention, described here as spectacular death sharing online. Based on the empirical study of sample cases-predominantly involving the death of white, often young, adults-I show how different kinds of spectacular death events are shared as small stories. I explore the key types of death selected for sharing online, the linguistic and narrative styling of these selections and the networked uptake of the shared stories of life and death. Addressing sharing practices of life and death at these different levels arguably allows an insight into the way the tellability of death is extended in digital time-spaces and its implications for the visibility of death, dying, and mourning. Sharing life and death as small stories of the moment is found to involve practices of death-writing of the moment, which are intimately connected to salient forms of broadcasting the self-online as life-writing of the moment (Georgakopoulou 2017). This mode of sharing offers a window to broader tensions arising from public displays of emotion and the changing-and often antagonistic-forms of testimony in contemporary networked societies.

Keywords: sharing, small stories, digital narrative, death-writing, mourning

\section{INTRODUCTION}

In 2009 Jensen was observing that 'we live in the age of life stories [...]. This is also the age of the witness, the age of testimony in which first-hand accounts, personal experience, life change and evolution are valued, for 
good or ill, over distanced reflection' (xxviii). As Gilmore notes, testimony continues to be a feature of contemporary life (307). Given the pull to animate contemporary experience through first-person accounts and testimonies, it should come as no surprise that death narratives are becoming increasingly popular as acts of bearing witness to different kinds of loss and as vehicles for coming to terms with the personal or social importance of a death event. Death narratives encompass autobiographical narratives of illness, dying, and mourning as well as public stories of death and mourning shared on social media. The scope of this article is restricted to the latter, as the aim here is to provide an empirical lens on the study of death as a media and social media event.

Public stories of life and death shared on social media contribute to the augmentation of the visibility of death. In addition, they re-emphasize death as a form of popular entertainment in line with market and media logics. In that respect, they present some similarities to obituary writing. As Ascherson and Bullamore note, obituaries are organised around a good, tellable story to mark a life, giving an appraisal and they feed into public interest in death as an event, asking, for example, how did it happen? what was it like? (29-32).

To gain a better understanding of public stories of life and death online one needs to consider how social media is changing the way we tell and share stories more broadly. De Fina and Georgakopoulou note that digital stories are co-created by multiple authors, without necessarily featuring a beginning, middle and end (122); they typically take the form of 'breaking news' or 'happening-now' stories (Page 429; Dayter 25). As Georgakopoulou (2017) shows in her research on sharing and updating the self on social media, digital narrativity largely emerges as life-writing of the moment. This mode of narrativity puts into question earlier understandings of narrative as a reflective sequencing of past events. Importantly, it attests to broader shifts in the socio-narrative constitution of personal experience and the self as narrative (Bruner 2004, 691) towards the constitution of personal experience and the self as sharing (John 2013, 178).

Social sciences constituted the self as narrative following the narrative turn in the 1970s and 80s, when autobiographical narratives became established as a way of knowing - a kind of thought that is different to logical thought, and which according to Bruner involves the transformation of 'the primary qualities of direct experience into the secondary qualities of higher knowledge' (Bruner 1991, 69). By 'transformation' is understood the sequencing of events over time and their placement in a meaningful context, endowing them with exceptionality (ibid, 71). Labov referred to this type of exceptionality as a story's tellability established 
through evaluation sections, i.e. parts of the story where the teller makes explicit the point of the story (5).

This long-held understanding of experience as narrative is now giving way to a new understanding of personal experience as sharing, whereby personal experience is constituted, understood, and constructed in and through particular practices of broadcasting — and curating — significant moments with networked audiences. According to Nicholas John (2017) 'ours is an age of sharing' and sharing is now a metaphor we live by (5). In practical terms, sharing refers to self-expression and the entextualisation ${ }^{1}$ of self, i.e. the construction of the self through text, written, spoken and/ or visual means (e.g. messages, videos, images). Sharing online involves the broadcasting of important life events and everyday happenings, political views, feelings and thoughts. In addition to life events, death also becomes shareable online in the form of breaking news of death and reactions to such news, posts of deathversary wishes, the broadcasting of funeral selfies or the curation of video diaries (vlogs) of living with terminal illness.

As a term sharing is a polysemic homonym that conveys what Raymond Williams calls a 'structure of feeling', a 'particular quality of social experience and relationship, which gives the sense of a generation or period' (qtd in John 2017, 156). Sharing forms 'a complex and contradictory set of practices and meanings through which we can read and make sense of large swathes of contemporary society; it is also a normative yardstick by which we evaluate the way we live' (ibid 157). In online contexts it involves, more specifically, the mediation and mediatisation of private experiences as a public process we often end up having little control over. It reconfigures the nature of public life and affords new forms of visibility (see Thompson; Baym and boyd; Giaxoglou et al.). This mediated form of visibility is characterized by the social media affordances of persistence (what we share stays online), replicability (what we share can be reshared and even become viral), scalability (local indexicalities can quickly attain global meanings) and searchability (our lives and selves can be tracked and we can track the lives of others) (boyd 45).

Even though there is a growing body of critical work on everyday stories of life events and moments online, there has been less systematic attention paid, so far, to everyday stories of death and the ways they are shared in the context of digital practices of mourning. This article seeks to fill this gap and provide discourse-narrative insights into emerging practices and norms for sharing death as small stories of the moment, i.e. small stories broadcast and distributed in the here-and-now. Sharing death online expands the tellability of death and raises important questions about the kinds of visibility afforded for death, but also for the dead and mourning 
subjects: where, when, and how is death shared online? How do networked users react to such forms of sharing in social media contexts? And how do these emerging norms of sharing death relate to broader political, market, and media ideologies, which, as Judith Butler notes, frame certain forms of testimony and grief as "nationally recognized and amplified [and others] as unthinkable and ungrievable' (xvi-xv)?

\section{SHARING LIFE AND DEATH AS SMALL STORIES OF THE MOMENT}

Depictions of death have always been part of the media as news and as entertainment (see Goldberg). Sharing death-related moments has also become an integral part of social media in practices relating to digital mourning. This is evident in the abundance of popular etiquette guides, for example, on Facebook memorializing (e.g. Mashable ${ }^{2}$ ) or Twitter "micro-mourning" (e.g. Slate online ${ }^{3}$ ), whereby mourning refers to a set of predominantly public displays of loss-related emotion online, subject to social platform affordances and constraints. As these etiquette guides suggest-and similarly to other types of sharing practices, both online and offline-death online is not a uniform practice across temporal, spatial, or user contexts. Rather, it depends on selections at different levels.

The first level of selection concerns the medium of sharing. Social platforms differ in the affordances and constraints they present to users, including for instance the configuration of one's social network ('friends' or 'followers'), the available materialities for posting and interacting, and the degree of user control over the publicness of sharing. Androutsopoulos has proposed an empirical approach for studying practices of sharing, examining selection practices alongside the interrelated practices of styling and negotiating significant moments with networked audiences (8). These three types of practices are used, here, as organising axes for the discussion of how significant moments relating to death and mourning are shared as different types of small stories.

Small stories is a research paradigm developed by Georgakopoulou that has marked an important shift from personal experience past event stories to "conversational small stories as crucial sites of subjectivity" (Georgakopoulou 2007, 89; see also Bamberg and Georgakopoulou 2008). This paradigm has opened up the scope and direction of the study of narrative as social practice embedded in other practices. It has also helped to address the complexities of narrative forms in new contexts and clarify new conditions and norms for their production and reception or interpretation. According to Georgakopoulou, small stories on social media normally: 'announce and perform minute-by-minute, often ordinary experience, develop in different media, are embedded into a variety of online and offline environments with 
different semiotic modes (e.g. verbal, visual) and may be sanctioned and recontextualised in unforeseeable ways by networked audiences with processes of like, share, and follow' (Georgakopoulou 2015, 266-267).

In this study I combine the empirical examination of sharing practices and small stories and examine in turn:

- the selection of the different forms in which death is shared online and the different kinds of death users select as reportable and shareable;

- the linguistic and narrative styling of posts: how users style their posts in the context of sequential posts in line with social media and narrative affordances;

- $\quad$ the negotiation of these shared moments with networked audiences and the uptake of small stories in circulation.

This perspective makes it possible to move beyond the description of the content of sharing death online. It also helps clarify key aspects of seemingly 'new' or 'reconfigured' ways of crafting, telling, broadcasting and distributing stories. The research questions addressed in this article include the following: (i) Whose death is selected as reportable and shareable? (ii) How is death and dying shared online as small stories? (iii) What is the networked uptake of this type of sharing?

A starting point for identifying and selecting key moments for analysis has been the notion of 'media event' (see Dayan and Katz) and its reconceptualization in a global age as the 'spectacular media event', which Kellner defines as 'certain situated, thickened, centering performances of mediated communication that are focused on a specific thematic core, cross different media products and reach a wide and diverse multiplicity of audiences and participants' (22). In my article, spectacular media events are seen to extend to social media "spectacles" around which networked audiences band and disband into 'affective publics' (see Papacharissi).

The cases discussed in this article are drawn from an ongoing research project on sharing stories of life and death online. Their selection aims to provide a broad overview of such practices, including cases of mass shootings, accidents, attacks, and celebrity death occurring at various times between 2007 and 2016 and sparking high levels of media and social media attention. The selected cases are ordered here in terms of the chronology of the events that prompted them:

(i) Five Facebook memorial public groups created in the wake of the mass shooting in Virginia Polytechnic Institute and State University (also known as Virginia Tech) in Blacksburg, Virginia, United States on April 16, 2007, which left 32 students and teachers dead. These memorials were created in addition to the official memorial website We Remember Virginia Tech; 
(ii) Three Facebook memorial public groups created in the wake of the school shooting on December 14, 2012 in Sandy Hook elementary school in Newtown, Connecticut, which left twenty children between six and seven years old and six adult staff members dead;

(iii) One semi-public Facebook memorial group, carefully managed and monitored by administrators and created by six of the closest friends of a young adult who lost his life in a car accident in 2012;

(iv) Facebook updates and Twitter posts in reaction to the attacks against the magazine Charlie Hebdo on January $7^{\text {th }}$, 2015;

(v) Twitter tribute posts and Facebook memorial public groups and pages created as a tribute to David Bowie who died on January 11, 2016.

My selection of the sample has been based on the public availability of texts and their explicit connection to media events and social media popularity indexes (i.e. number of comments, reshares, etc.). The relatively broad temporal span of this selection is part of my attempt to foreground that small stories of life and death online share some typical characteristics of sharing and storying online, irrespective of the particular event they are associated with.

The majority of the sample examples relate to events and users in the US. This is partly due to the fact that these pages and groups were open to public view and were, hence, more readily available for study. An additional reason for choosing to focus on US social media events is the high degree of social media penetration ${ }^{4}$ in the United States, which foregrounds the increased importance that social media plays in the life of a large part of the American population. As Christensen and Gotved note, death-related coping practices on Facebook are related to Facebook being an everyday way of communicating feelings, practices, and immediate thoughts (4); the basic establishment of online social technologies in people's everyday life is, thus, an important condition for the popularity of digital mourning practices. As Klastrup, who focuses on Danish R.I.P. memorials notes, however, there are 'cross-cultural variations as to how RIP pages might function compared to the USA' (148), though these are beyond the scope of this article.

Reactions to the Charlie Hebdo attacks have been also included as they show how practices of sharing grief using popular hashtags result in 'new' forms of visibility for certain deaths, but not others. This is also the case for the selection of David Bowie's tributes showing continued postmortem affection to a celebrity both online and offline.

The adaptation of social media sites for mourning exhibits commonalities in terms of the affordances and norms available to users for sharing their stories and tributes. The selected cases are all examples of highly 
visible deaths taken to showcase public mourning online with and for global networked audiences across different social network sites. My analysis is based on the unit of the wall event (on Facebook), which Androutsopoulos describes as an initiating post followed by 'likes', and one or more responding contributions by members of the audience (8).

\section{SELECTION PRACTICES: SHARING DEATH AS BREAKING NEWS AND REACTIONS}

Even though all death can be seen to be equally reportable as an important event that disrupts the everyday flow, not all death is equally tellable and shareable as breaking news stories on social media. On MyDeathSpace, ${ }^{5}$ for example, MySpace ${ }^{6}$ accounts of deceased users based in the US are recorded on a map of the United States. Users can 'submit a new death' (see Figure 1), browse death news and announcements, and also share their views and comments in the space of discussion forum threads. In this context, the death of any MySpace user counts as reportable as long as it is logged on DeathSpace; for users located in the U.S. death is also visually reportable on the death-map.

\section{S MyDeathSpace.com}

\section{HOME ARCHIVE FORUM MISSING PERSONS CRIMINALS}

\section{Submit a new death}

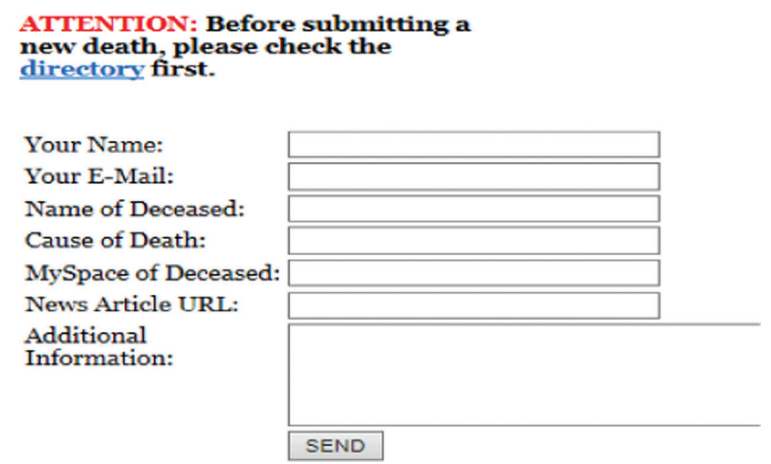

Figure 1. MyDeathSpace online form for submitting a new death. 
MyDeathSpace also has a Facebook Page, ${ }^{7}$ described as 'Collecting the deaths of Social Networkers since 2005' and counting 18, 211 likes at the time of writing. This page features a news-like feed of online obituaries, i.e. remediations of news articles reporting the recent death of a person, including a short account of their life, a picture of the deceased, and information about upcoming memorial services. Below the news broadcast, there is a comments space open to users' reactions. Looking at the different types of death reported in this space, it is notable that the majority of reported deaths involve the death of young individuals whose lives-and by extension their social media lives-have been cut short because of an accident, a terminal illness, or mass death, e.g. shootings or attacks.

Selection practices in this dedicated deathspace do not simply involve the selection of social networkers' deaths, but rather the selection of spectacular deaths-individual or mass-as reportable, and hence entextualisable. Breaking news of death on MyDeathSpace weaves, thus, a public spectacle of highly reportable death and opens it up for public comment. MyDeathSpace attests to early forms of the mediatisation of death, both online and offline, as "newsworthy" material. As Klastrup notes news of death 'shocks and allows for emotional arousal; it is the type of news which allow for identification with the bereaved in particular when it is well-known celebrities or people like us (or our sons and daughters) who die [...]' (150-1).

In addition to MyDeathspace, Facebook has been appropriated by users as a site for digital memorialisation unfolding in memorial pages, groups, and memorialized accounts or one-off posts in users' personal profiles. Other sites used for mourning activities include Twitter and Instagram, where sharing predominantly happens in the space of image captions or hashtags, such as \#RIP, \#Remembering, \#flyHigh. Similar to MyDeathSpace, selections of death in these 'new' social platforms range from highly mediatised spectacular cases of mass death, such as school shootings and terror attacks, cases of the sudden and tragic loss of young individuals, and prominent cases of celebrity death. Unlike DeathSpace, where death sharing is organised around a constant flow of breaking news of different spectacular death events, on Facebook (as on other social media platforms) the focus is on a single spectacular death event in a dedicated space, which is marked off from users' personal profiles. The mediatisation of death online in these spaces, thus, involves the sharing of breaking news of specific death events around which a continuously updated feed of reactions and comments on its affective impact accumulates.

Posts in these dedicated memorial spaces often remediate news reports from media sources, as shown in Example 1, taken from one of the Sandy Hook memorials (see Figures $2 \& 3$ ). The post includes an extract of a 
CBS article reporting the flood of reactions to the shooting alongside an image of a local memorial, which further attests to the public's reaction to the school shooting.

\section{Example 1}

\section{Sandy Hook}

$\triangle \varepsilon \kappa \varepsilon \mu$ @íou 21, 2012 - •

(CBS News) Memorials and funeral processions continue to jam the small streets of Newtown, Conn. today, which marks one week since the shooting rampage at Sandy Hook elementary on Friday, Dec. 14. Last night, the family of Sandy Hook first-grader Emilie Parker, who was killed in the shooting, held a memorial near the Utah town where she was born.

At the memorial, her father Robbie Parker said, "even though this was very personal, I started to realize how this touched everybody, everywhere." And as people across the country join in their mourning, mayors and governors across the U.S. have called fora moment of silence Friday morning at 9:30, to mark the week of mourning and organizers on Twitter and Facebook have called for a virtual moment of silence at 9:30, asking for a pause on tweets or posts for five minutes.

The local post office has inundated with expressions of sympathy from around the world. "We're getting cards, we're getting letters, packages ... something that they want to provide to the family for comfort," Newtown postal worker Christine Dugas told CBS News' Seth Doane.

The Newtown post office is receiving thousands of piece of mail daily, "from as far away

as England, Siciliy, Australia, and every part of this country," Dugas said. Others are taking to the Internet to share their thoughts with families in Newtown, using sites like Evergram, where users are uploading video messages and notes.

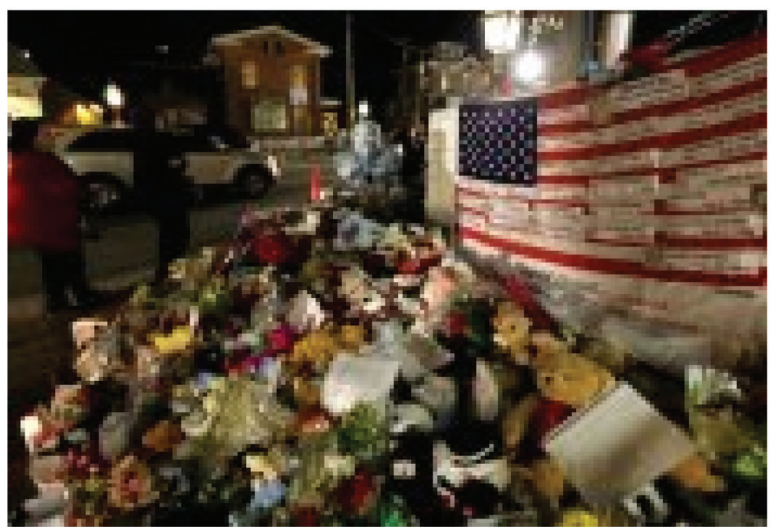

Figures $2 \&$ 3. Remediating a news report on Facebook group Rip Sandy Hook Angels.

The selection of this news report seeks to construct the event as a global media and mediatised spectacle and contribute to its amplification in a more persistent, replicable, searchable, and scalable way. The post calls 
for social media users' engagement with the death event via liking, sharing or adding a comment below the post. And yet the limited number of likes in this case (three likes; no shares), which is similar to other memorial posts and sites, suggests that the intention of boosting public participation online is not necessarily realised in practice; rather, the act of creating impromptu memorial pages as a form of users' personalised breaking reaction to spectacular death events becomes, in its own right, a measure of online public engagement with such events.

The salience of immediate reactions to the news of spectacular death is also attested in posts recording memorial activity. These take the form of visual recontextualisations of offline memorials (see Example 2, Figure 4), injunctions to join planned memorial activities, such as wearing tribute colours on deathversaries (see Example 3, Figure 5), or deathversary posts (see Example 4, Figure 6).

\section{Example 2}

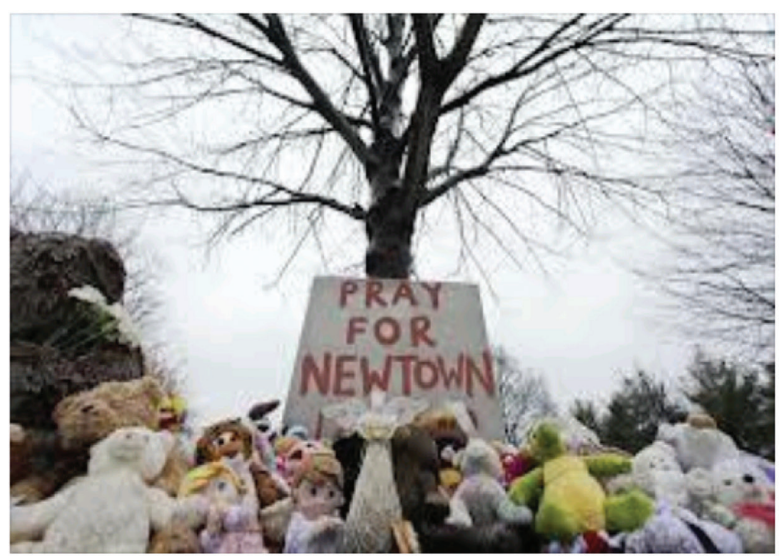

$\Rightarrow$ Share

(1) 2

Figure 4. Memorial post on Facebook group R.I.P. Sandy Hook. 


\section{Example 3}

Sandy Hook Elementry Rip

$\triangle \varepsilon \kappa \varepsilon \mu 6 \mathrm{QIOU} 19,2012 \cdot \bullet$

\section{remember to wear white and green this friday}

Share

12

Figure 5. Memorial post on Facebook group Sandy Hook Elementary Rip.

\section{Example 4}

Rip Sandy Hook Victims

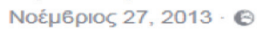

\section{It's been almost a year since the sandy hook tragedy. Still remembering,}

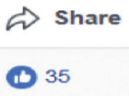

Figure 6. Memorial post on Facebook group Sandy Hook Victims.

Such reactions point to the predominantly memorialising function of these sites. In some memorial groups and pages, this memorial function is foregrounded by posting the names, images, and stories of the victims, creating a shareable testimony of their lives.

Mass shootings in the US constitute, of course, a special case in question, as they are becoming increasingly normalised; as a result, media and social media reactions are becoming increasingly conventionalised, too. As Hutchins notes, politicians and the wider public first offer their thoughts and prayers, and then American media flood their pages with updates and comparisons with previous shootings in an attempt to convince the public that this shooting should mark a change in the country's gun laws, while gun lobbies resist even the smallest change. This creates an affective frame that connects mass shooting events to wider debates about gun ownership and violence. Sharing reactions to mass shootings online becomes part of bearing witness to the wider cultural phenomenon of gun-related deaths 
and contributes to the creation of normative frames for these types of innocent and often young victims as publicly grievable deaths.

The next section turns to the closer consideration of how death is shared online, both in terms of the general linguistic style and the narrative dimensions of this type of sharing.

\section{STYLING PRACTICES: THE LANGUAGE OF DEATH ONLINE}

The style of posts sharing death online echoes genres of condolences and conventional expressions of sympathy as attested, for example, in written messages and books of condolences. What typically sets these posts apart from other social media posts, and motivates their designation as memorial updates, is the use of the abbreviated expression R.I.P. (Rest in Peace). The expression has been commonly used as an epigraph on gravestones representing the farewell words of the living to the dead. In this new context of memorialising, the abbreviation R.I.P. is now a common linguistic resource used by strangers - instead of family_in styles that range from formal (Example 5) to more vernacular styles (Example 6) in line with norms of digital writing (see Tagg).

\section{Example $5^{8}$}

R.I.P.

GOD BLESS THEIR FAMILIES AND FRIENDS AND EVERYONE ELSE! (Source: Facebook Sandy Hook memorial, Group 1)

\section{Example 6}

R.I.P. man...u are missed and loved by many

(Source: Facebook Memorial group for the loss of a friend)

Memorial posts are, predominantly marked by the use of R.I.P. at the opening or closing position, although this is not always a requirement, as Examples 7 \& 8 illustrate.

\section{Example 7}

God bless them all.

(Source: Facebook Sandy Hook memorial, Group 1)

\section{Example 8}

We'll never forget any of you, ever.

(Source: Facebook Sandy Hook memorial, Group 1) 
Their explicit orientation to either the bereaved families (Example 5) or the victims (Examples 6, 7, 8) seems to be their defining discourse characteristic of these messages: as Walter observes "social and digital media have an uncanny ability to link mourners not only with each other but also with the dead. [...] social media post-mortem posts are often not about the dead, but addressed to them" (105). Direct addresses to the dead echo the literary figure of apostrophe whereby the speaker directs speech to a third party, often absent from the scene. These also feature in traditional genres of mourning, as for example the ManiatGreek laments for the dead, whereby the lamenter "talks" to the dead addressing them in the second person pronoun to articulate her pain and publicly raise the consequences of the death for those left behind (see Giaxoglou 2008).

Memorial updates like the ones described above are typically encountered in public or semi-public memorials. As Klastrup notes they are used to articulate a fleeting expression of sympathy from unconnected individuals 'like a candle or a flower left by a stranger, never to return to the site again' (161). This type of comment represents public mourning online and creates social media spectacles of affect with and for networked audiences.

\section{ECSTATIC SHARING OF BREAKING NEWS STORIES}

Social media spectacles of affect are intricately connected with breaking news stories in the media. As the case of one of the R.I.P. Virginia Tech memorials illustrates, breaking news stories involve users' entextualisation of their own affective reactions to the media's coverage of the news. In their memorial updates, users often make an explicit reference to the immediacy or recency of the news of the shooting that reached them, using that media connection as a frame for projecting their identification or sympathy with the victims and their bereaved families, even if they weren't acquainted with them (see Examples 9-10).

\section{Example 9}

what a horrible thing to have happened. i can't imagine what is going through the minds of everyone involved. just seeing the news reports and interviews, ${ }^{9}$ i can't help but feel sick to my stomach. i know that i'll keep those people in my thoughts and prayers.

Source: R.I.P. Virginia Tech, Facebook Group 1 


\section{Example 10}

when $\mathrm{i}$ heard about the virginia tech shooting my heart dropped. one of my friends goes there and i have never been so terrified. God bless the families who lost their children today. This just teaches everyone how life can be taken so quickly and we must live for those moments that make life unbelievably amazing.

Source: R.I.P. Virginia Tech, Facebook Group 1

This method of breaking news stories online echoes the ecstatic modes of live news reporting on global spectacles of tragedies and suffering in the instant proximity of the here-and-now, which as Chouliaraki shows, positions viewers as witnesses to distant suffering (5). Breaking news stories online need to be understood as part of what Papacharissi and Oliveira call the affective news streams produced by networked publics, combining news, opinion, and emotion with an always-on affective feed (280). Sharing death online is arguably an extension of ecstatic modes of news reporting to online contexts, and can be described as ecstatic sharing. Ecstatic sharing is not so much about distributing factual information; it's about prompting the affective participation of those in the instantaneous proximity of the here-and-now and enhancing - as well as maintaining - the visibility of reported events or happenings.

The concern for maintaining the visibility of the affective importance of a death event is evident in the context of ecstatic sharing around deathversaries. This type of sharing is common in tributes to victims of mass shootings as well as in memorial R.I.P. Facebook semi-public groups dedicated to the loss of a friend (see Example 11). In the latter, users also tend to stop by the memorial site more than once and share stories of their own here-andnow long after the death event has happened (see Examples 12 \& 13). In that respect they attest to users' deeper and longer-term engagement with the death event and its impact on themselves and other members of the group at the same time as extending to news of posters' own everyday lives. This allows users to re-integrate the dead into the everyday and enhance their proximity to them and the community of those left behind.

\section{Example 11}

rip davey! love you so much, and miss you like crazyy! I have no doubt in my mind you are doing it big up there! ( :

\section{Example 12}

Just stopping by to say whats up and see how you doing man.....i ran into your parents unexpected the other day ....it was good seeing them... Miss you and love you man!!! 


\section{Example 13}

The suns setting over the lake right now and it's turning the sky orange and blue. Couldn't help but stop and think for a minute about how pretty it must be up where you are.

Ecstatic sharing is further illustrated in the case of hashtag mourning, most notably in the case of reactions to the Charlie Hebdo attacks in Paris, France in January 2015 (and later on in similar attacks that hit Ankara, Paris, Brussels, Manchester, Barcelona, and London). In this case, instead of dedicated memorial groups or pages, it is hashtags that turn into spaces of connection. This mode of sharing affords users the possibility of linking with much bigger communities, heightening both the visibility of the death event and that of the user.

As I have noted, hashtag mourning is a "mode of mediatised experiencing of global events [creating] dividing lines of narrative stancetaking and identification" (Giaxoglou 2018, 19). This mode makes available legitimising as well as critical assessments of the events and people involved. The hashtag \#JeSuisCharlie, ${ }^{10}$ for example, projects an identification with the victims at the offices of Charlie Hebdo. As a powerful gesture of affect, the hashtag \#JeSuisCharlie encoded sentiments of national and global unity that were quickly accompanied by the upholding of Western attitudes about freedom of speech-as well as by counter-hashtags calling out the partiality of such expressions of solidarity to Western attacks and victims (e.g. \#JeNeSuisPasCharlie, \#NotInMyName, \#JeSuisAnkara, \#JeSuisCongo). The use of hashtags allows users to inhabit positions of personalised witnessing of death, and they also make it possible for users to participate to global flows of affect. Such flows amplify the voice of new witnesses and mobilise offline action as in the case of the movement \#BlackLivesMatter, where, as Gilmore notes, acts of networked testimony become part of 'what's next', rather than bearing witness to 'what's happened' (307).

Despite the centrality of the mode of ecstatic sharing across different types of digital mourning acts, the particular displays of affect differ with respect to whether they are part of mass mourning, best described as parasocial, i.e. mourning for the loss of people one doesn't know or knows very little, or whether they are part of personal grieving for the loss of a loved one, attesting to the way digital practices have brought 'death and mourning out of the closet, weaving it into the warp and woof of everyday life' (Walter 2015, 14). And yet, irrespective of the site in which it takes place, the ecstatic sharing of death online allows for death to be individualised within a collective, shared space enabling 'grieving to be experienced both privately and collectively, and even at community level' (Bourdeloie and Julier-Costes 133). 


\section{STYLING PRACTICES: NARRATIVE DIMENSIONS OF SHARING DEATH ONLINE}

Participation is one of the key narrative dimensions of sharing death online. As the following example illustrates, memorial posts on social platforms, like Facebook, form part of series of spatially contiguous posts, which appear in reverse chronological order. The four posts below date from 2015; they have been extracted from a longer sequence of memorial birthday wishes posted on a Facebook group in remembrance of a young adult who lost his life in 2012.

Example 14 (from Facebook memorial group) ${ }^{11}$ :

(a) Why do i miss your birthday every year by one day?? Its rediculous [sic] lol but i still think about you every day *:) miss you!!!!! Happy belated birthday

(b) Happy birthday! Love and miss you everyday!

(c) Happy birthday bro. Miss you man

(d) Happy Birthday!!! I think of you everyday!!! Love and miss you.........

In the above sequence, posts mirror one another lexically, syntactically, grammatically and sequentially. The content of each post includes a formulaic expression of birthday wishes and an expression of remembrance, in some cases punctuated by the use of emoji (see Examples a \& b). The stylistic congruence of these posts suggests that users are highly likely to have read each other's posts before adding their own. By posting mirroring contributions as a reaction to the first post flagging up the day as a day of remembrance, users show their alignment to the display of affective stance in the original as well as in subsequent posts. In that respect they are similar to comment reactions to selfies, where, as Georgakopoulou has shown, alignment involves displaying affiliation with the portrayed self and serves to validate a self-branded self $(2016,309)$.

In the above example, users engage in a ritualised process of interactional alignment to each other creating a sense of a collectivity, banding mourners into a group reacting alone, together (cf. Turkle). This practice marks off these acts as separate from everyday sharing where showing alignment to others' posts via likes, comments or shares is a key part of online participation; it could be also taken to suggest some level of uncertainty about how to behave when sharing reactions to death or displays of emotion online (see Wagner, 2018).

A similar kind of mimetic posting activity is typical in the context of celebrity death on Facebook. As the example below taken from a Facebook page in tribute to David Bowie, followed by 7,448 users, activity is 
largely organised around sharing and commenting on the idol's pictures. The comments below are taken from the first wall event on the page, namely the sharing of an image of David Bowie's alter ego, Ziggy Stardust, on the day of the news of his death.

\section{Example 15:}

\section{Comments}

(a) USER6 for ever my Hero I'm a rich man to know you from the albums: "Heroes", "the man who sold the world" and "Best of Bowie". January 17, 2016 at 5:02p.m.

(b) USER5 Thank you for the magic both by your music and acting skills (Labyrinth). I shall never forget that smile.

January 13, 2016 at 10:57p.m.

(c) USER4 You taught me to really think....at early teenage years..... thank you....dx

January 13, 2016 at 10:37p.m.

(d) USER3 Grateful for your music and for who you were! One of the heroes of art.

January 12, 2016 at 8:52p.m.

(e) USER2 miss u david

January 12, 2016 at 7:42p.m.

(f) USER1 ALLADINSANET

January 11, 2016 at 6:45p.m.

Comments mirror one another lexically, despite being syntactically and grammatically variable. The iterative use of positive assessments of David Bowie as a 'hero' and the expression of thanks and gratitude display contributors' alignment to the stance communicated in other posts and validate the celebrity 'character' post-mortem. In addition to aspects of stylistic congruity, contributions often include displays of what Georgakopoulou (2016) refers to as knowing participation, i.e. the display of some knowledge that goes beyond the here-and-now. As she has shown in her analysis of selfies, knowing participation serves to demarcate friends in the know from other friends.

In this case users make reference to their own personal connection to the musician (Example 15c), prompting chains of 'second' stories of ritual acknowledgement and knowing participation (Examples 15a, b) which help demarcate knowledgeable fans from 'bandwagon' fans. Acts of knowing participation serve as a way for contributors to claim their entitlement to join in the crowd of celebrity mourners and participate in the sharing as 'entitled' fans. 
In addition to this type of mimetic sharing where posts take their meaning from the sequential accumulation of posts, there are also instances of posts which do not rely on the spatial contiguity of memorial walls. These involve micro-mourning updates shared on a user's personal timeline (on Facebook) or feed (on Twitter). Their narrative constitution relies on the cross-site aggregation of tributes around hashtags, such as \#DavidBowie and memorial hashtags \#RIPDavidBowie in the case of celebrity death.

Example 16: Facebook update

RIP \#DavidBowie, a humble genius, a music phenomenon, a genuine eccentric, a true legend. We shall live in your stardust forever $\mathrm{X}$.

As illustrated in Example 16, these posts make positive assessments of the celebrity, offering more concise and transportable assessments compared to Facebook comments (see also Example 17, Figure 7). Even though they are not interactionally aligned to posts on the wall they appear in, they show ritual acknowledgement and knowing participation in relation to posts that appear on other sites, as for example memorial tweets posted by celebrities shortly after the announcement of David Bowie's death. Aggregating posts contribute to the collective post-mortem storying of the celebrity as a brand as well as the banding and bonding of individual users into affective fandom publics.

\section{Example 17:}

Talented. Unique. Genius. Game Changer. The Man who Fell to Earth. Your Spirit Lives on Forever! 1 \#rebelheart 9:01 AM - 11 Jan 2016

\& ᄂ7 4,569

6,997

Figure 7. Tweet about the death of David Bowie on Madonna's official Twitter account.

Sharing death online, whether a friend's death or the death of a celebrity, is found to involve acts of ritual appreciation, and knowing participation. These reactions are best understood as small stories, that call users to align with other users' stances; they also invite users to project postmortem relationships to the dead in ways which affirm the deceased's relevance to the here-and-now at the same time as re-establishing the dead as an absent presence. 
My final section looks briefly how shared moments of death are negotiated with networked audiences.

\section{NEGOTIATING WITH NETWORKED AUDIENCES}

The memorial walls of Facebook groups for Sandy Hook and Virginia Tech victims are made up of stand-alone wall events involving single text-based posts. Across the different groups examined, individual posts received no likes at all and commenting under such posts was rare. In the closed Facebook memorial group created for the loss of a friend, there was a similar avoidance of liking or commenting on posts pointing to a form of digital silence comparable to the respectful silence of language surrounding offline bereavement rituals. Exceptions to this practice include the sharing of a song dedicated to the deceased or posts prompting offline memorializing activity.

Facebook memorial groups for David Bowie, on the other hand, attracted multiple likes, shares, and comments, in particular centred around pictures of the idol, as shown in the example below (see Figure 8). The black and white image is taken from one of the R.I.P. David Bowie Facebook pages counting 7583 followers, and was considered more closely on account of its being the most popular post, i.e. the post that has attracted the highest number of reactions (38 comments in total, 680 likes).

\section{Example 18.}

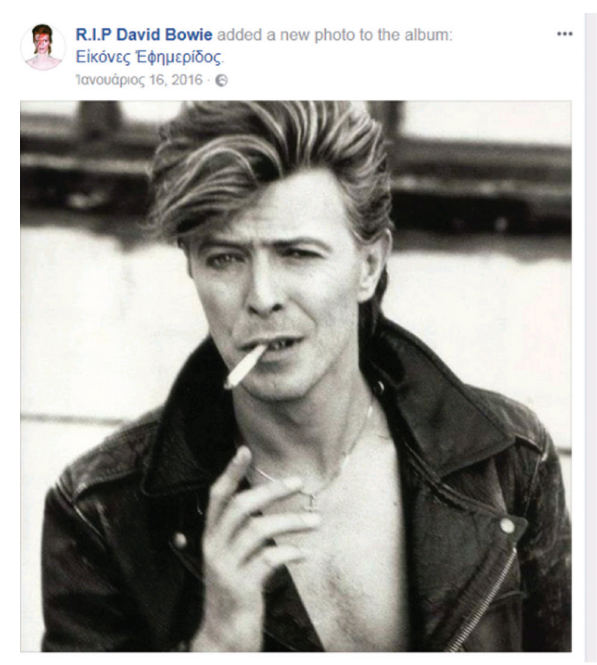

Figure 8. Image of David Bowie on Facebook page R.I.P. David Bowie. 
The comment space below this picture accumulates small stories of affective participation, shared as acts of ritual appreciation and knowing participation, as discussed in the previous section. Some posts focus on the appearance of the idol either verbally (e.g. 'Wooh'!; 'beauty!'; 'incredible David') or non-verbally (e.g. using emojis expressive of love and admiration). Other contributors seek to display the poster's relationship to the celebrity ('I loved him since I was $12 \ldots$ still got all my vinyl albums... Will never part with them... I miss him and although I never met him there is a massive void in my life'; 'everytime I see a picture or hear his music I cry'), while others share brief memorial posts ('RIP David', 'miss him', or sad-faced stickers and emojis). Similar to the Virginia Tech, Sandy Hook memorial walls and the Facebook memorial group for the young adult discussed above, there is little direct interaction between contributors on this memorial wall.

This range of post types attests to the diverse ways in which users orient to normative expectations for memorial posting not only across different types of death and sites, but also within the same memorial space. Contributors negotiate the story recipiency positions of alignment or disalignment available to them in an attempt to project a fragment of their own experience, feelings, or memories to the collectively woven post-mortem story of their idol.

\section{CONCLUSIONS}

Sharing death online is generally organised around: (i) the selection of spectacular death attracting high levels of media attention, (ii) the styling of death as breaking news stories, e.g. as one-off announcements of death, memorial posts or updatable reactions to the death event and (iii) the creation of story recipiency positions of alignment or disalignment to other users, allowing one to project themselves as an entitled mourner, a member of a group or crowd of mourners, a remember(er), a celebrity fan, or a co-mourner and co-sufferer. Sharing small stories of death online has been described here as a mode of ecstatic sharing, i.e. sharing in the instantaneous proximity of the here-and-now, and foregrounding affectivity in immediate reactions to death.

The popularisation of sharing death online alongside the injunction to share immediate reactions to death events, irrespective of one's proximity to those involved, opens up tensions and ambivalences in the reception of such practices. This is evident in the case of memorial page trolling. This may include the posting of disruptive and offensive comments in memorial sites or the hijacking of stories and pictures of the dead and their viral circulation as memes. A common trope of this type of trolling is the social 
media circulation of photographs of alt-right 'comedian' Sam Hyde as the perpetrator in the wake of Las Vegas attacks, but also earlier mass shootings and terror attacks. Activities of this type are known among users of social media subcultures (e.g. users frequenting the forum 4Chan) as "RIP trolling" or "LOL trolling" (Phillips). In addition, trolling in the case of mass shootings in the US is found to be enmeshed in debates around gun control. In the case of Sandy Hook shootings, parents of victims were re-victimised by conspiracy groups making claims via Facebook that the massacre was a hoax ${ }^{12}$; after the Florida high school shooting on February 14, 2018, trolls and bots intervened in social media conversations around \#floridaschoolshooting tweeting about gun control and the alleged shooter in an attempt to shape the public story around the attacks. ${ }^{13}$

Trolling behaviour is often condemned in the media as evidence of the increasing lack of sensitivity to the pain of others or as one of the outcomes of the anonymity of the internet. Some of the trolls that Phillips interviewed, however, said that their trolling activity was attacking grief strangers because they were not really connected to the death and were not really in mourning; in that respect trolls are seen to act as the "grief police" making judgments about what counts as authentic or fake mourning. Trolls claim they target memorial pages "for the lulz"-i.e. the antagonistic laughter derived from the infliction of emotional distress-and often in reaction to media's sensationalising coverage of death events turning tragedy into merchandise (Phillips and Milner). As much as these trolling behaviours can be seen as outrageous and insensitive, they also constitute important sites for the exploration of the tensions and ambivalences of sharing online in relation to ideologies of emotion and mourning. As Phillips and Milner show such behaviours are not 'new' but rather have pre-internet antecedents in a range of behaviours that seek to challenge, comment on and subvert socially acceptable practices (38-44). The increase of algorithmically-enabled trolling in the case of mass shooting events in the US, however, further points to the mobilisation of trolling for political purposes in the US, which are worthy of investigation in their own right.

Undoubtedly, the mediatisation of death, mourning, and memorialization on and via social media has opened up questions of thanatosensitivity, i.e. questions about what is appropriate when it comes to the sharing of death, not only for users and the wider public, but also for computersystem designers and social network companies. To address these questions, we need to better understand the function of individual users' expressions on online memorial sites, including trolling behaviour. One could view these sites as virtual examples of vernacular "spontaneous shrines", such as public roadside memorials, flower tributes outside the 
house of the dead or shrines at national disaster sites, often functioning as (semi) public sites of mourning.

Practices of digital mourning discussed here involve remediated practices rather than entirely 'new' practices of coping with death, which involve an emphasis on evaluative assessments. They extend the tellability of death by turning death events into occasions for telling and sharing moments, thoughts, feelings, and experiences in the here-and-now, with and for others. They also contribute to the cumulative co-construction of stories of life and death, projecting and curating special kinds of post-mortem identities and bonds. These small stories depart from canonical autobiographical tellings of mourning or illness in that they are not explicitly intended as empowering or voicing individual sufferers or groups. Rather, these kinds of small stories of the moment enable the wide distribution of assessments of the death event and the dead, transforming deathlogging practices (see DeathSpace) into an emerging form of multi-authored and cumulative death-writing of the moment.

Closely linked to media framings of death stories, public expressions of mourning online largely participate in the dominant politics of death. By selecting and making visible deaths that make the headlines they reinforce mainstream ideas about which lives are grievable and which are less so. In the cases I discussed in this article digital mourning manifests as an extension of sharing moments of life, expanding, amplifying and reinforcing the cultural orientation to optimistic, positive mourning and post-mortem happiness rather than inscribing aspects of the painful work of mourning. This article has not addressed the personal stories shared in the case of deaths in the family, even though this is a particularly interesting area in which the proposed framework of sharing as small stories could prove useful.

There is also much scope in exploring more systematically the relationship between news media and digital social platforms in practices of public and mass mourning. Further empirical investigation of affective sharing online across different contexts and practices could clarify aspects of the personalisation of globally circulating affective flows and the implications of these processes on the visibility and place of death, dying, and mourning in contemporary networked societies.

\section{WORKS CITED}

Androutsopoulos, Jannis. "Moments of Sharing: Entextualization and Linguistic Repertoires in Social Networking." Journal of Pragmatics (Special Issue edited by Pilar Garcés-Conejos Blivtich E Patricia Bou-Franch on Participation E New Media) 73 (2014): 4-18.

Ascherson, Neal and Tim Bullamore. "Neal Ascherson and Tim Bullamore in Conversation. July 6, 2007, Kingston University." Eds. Meg Jensen and Jane Jordan, Life Writing: The Spirit 
of the Age and the State of the Art. Newcastle upon Tyne: Cambridge Scholars Press, 2009. $30-32$.

Bamberg, Michael and Alexandra Georgakopoulou. "Small Stories as a New Perspective in Narrative and Identity Analysis." Text E Talk 28 (2008): 377-396.

Baym, Nancy and Danah Boyd. "Socially Mediated Publicness: An Introduction." Journal of Broadcasting Ẽ Electronic Media 56.3 (2012): 320-329.

Bourdeloie, Hélène and Martin Julier-Costes. "Deathlogging: Social Life Beyond the Grave: The Post-Mortem Uses of Social Networking Sites." Ed. Stefan Selke. Lifelogging. Digital selftracking and Lifelogging - between disruptive technology and cultural transformation. New York: Springer, 2016. 129-149.

boyd, danah. "Social Network Sites as Networked Publics: Affordances, Dynamics, and Implications." Ed. Zizi Papacharissi. A Networked Self: Identity, Community, and Culture on Social Network Sites. London and New York: Routledge, 2010. 39-58.

Bruner, Jerome. "Life as Narrative.” Social Research 71.3 (2004 [1986]): 691-710.

Bruner, Jerome. "Self-Making and World-Making." The Journal of Aesthetic Education (Special Issue: More Ways of Worldmaking) 25.1 (1991): 67-78.

Butler, Judith. Precarious Life. The Power of Mourning and Violence. London and New York: Verso Books, 2004.

Chouliaraki, Lilie. The Spectatorships of Suffering. London, Thousand Oaks, New Delhi: Sage Publications, 2006.

Christensen, Dorthe Refslund and Stine Gotved. "Online Memorial Culture: An Introduction." New Review of Hypermedia and Multimedia 21 (2015): 1-9.

Dayan, Daniel and Elihu Katz. Media Events: The Live Broadcasting of History. Harvard: Harvard University Press, 1994.

Dayter, Daria. "Small Stories and Extended Narratives on Twitter." Discourse, Context and Media 10 (2015): 19-26.

De Fina, Anna and Alexandra Georgakopoulou. Analysing Narrative: Discourse and Sociolinguistic Perspectives. Cambridge: Cambridge University Press, 2012.

Georgakopoulou, Alexandra. Small Stories, Interaction and Identities. Amsterdam: John Benjamins, 2007.

Georgakopoulou, Alexandra. "Life Writing of the Moment: The Sharing and Updating of the Self on Social Media." Ego-Media 2015. http://www.ego-media.org/projects/life-writing-of-the-moment-the-sharing-and-updating-self-on-social-media/. Accessed: 29 April 2019.

Georgakopoulou, Alexandra. "Small Stories Research: Methods-Analysis-Outreach." Eds. Anna De Fina and Alexandra Georgakopoulou. Handbook of Narrative Analysis. Malden, MA: Wiley-Blackwell, 2015, 255-272.

Georgakopoulou, Alexandra. "From Narrating the Self to Posting Self(ies): A Small Stories Approach to Selfies." Open Linguistics 2 (2016): 300-317.

Georgakopoulou, Alexandra. "Small Stories Research: A Narrative Paradigm for the Analysis of Social Media". Eds. Luke Sloan and Anabel Quan-Haase. The SAGE Handbook of Social Media Research Methods. London: Sage, 2017. 266-283.

Giaxoglou, Korina. Maniat Laments as Narratives: Forms and Norms of Entextualization. PhD Thesis (unpublished). London: King's College London, 2008.

Giaxoglou, Korina. "\#JeSuisCharlie? Hashtags as Narrative Resources in Contexts of Ecstatic Sharing." Discourse, Context, and Media 22 (2018): 13-20.

Gilmore, Leigh. "Testimony." Auto/Biography Studies 32.2 (2017): 307-309.

Goldberg, Vicki. "Death Takes a Holiday, Sort of." Ed. Jeffrey H. Goldstein. Why we watch: The Attractions of Violent Entertainment. New York, NY: Oxford University Press, 1998. $27-52$. 
Hutchins, Aaron. "Florida School Shooting: Charting the 'Normalization' of Gun Attacks on U.S. kids." In MacLean's [online]. Available at: http://www.macleans.ca/politics/ worldpolitics/florida-school-shooting-charting-the-normalization-of-gun-attacks-on-us-kids/. Accessed: February 172018.

Jensen, Meg. "Introduction. Do you Speak Life Narrative?" Eds. Meg Jensen and J. Jordan. Life Writing. The Spirit of the Age and the State of the Art. Newcastle upon Tyne: Cambridge Scholars Publishing, 2009. xvii-xxxiii.

John, Nicholas. "Sharing and Web 2.0: The Emergence of a Keyword." New Media Ev Society 15.2 (2013): 167-182.

John, Nicholas. The Age of Sharing. Malden, MA: Polity Press, 2017.

Kellner, Douglas. Media Spectacle. London and New York: Routledge, 2002.

Klastrup, Lisbeth. "'I didn’t know her, but...': Parasocial Mourning of Mediated Deaths on Facebook RIP Pages.” New Review of Hypermedia and Multimedia 21.1-2 (2015): 146-164.

Labov, William. The Language of Life and Death. The Transformation of Experience in Oral Narrative. Cambridge: Cambridge University Press, 2013.

Page, Ruth. "Narrative." Eds. Christian Hoffman and Wolfram Blubitz. Pragmatics of Social Media. Germany: Mouton de Gruyter, 2017. 523-544.

Papacharissi, Zizi. Affective Publics. Sentiment, Technology, and Politics. Oxford: Oxford University Press, 2015.

Papacharissi, Zizi and M. Maria de Fatima Oliveira. "Affective News and Networked Publics: The Rhythms of News Storytelling on \#Egypt." Journal of Communication 62 (2012): 266-282.

Phillips, Whitney. "LOLing at Tragedy: Facebook Trolls, Memorial Pages and Resistance of Grief Online." First Monday 16.12 (2011). n.p.

Phillips, Whitney and Ryan M. Milner. The Ambivalent Internet. Mischief, Oddity, and Antagonism Online. Malden, MA: Polity Press, 2017.

Tagg, Caroline. Exploring Digital Communication. Language in Action. London and New York: Routledge, 2015.

Thompson, John B. "The New Visibility." Theory, Culture EO Society 22.6 (2005): 31-51.

Turkle, Sherry. Alone Together. Why we Expect more from Technology and Less from Each Other. Cambridge, MA: MIT Press, 2011.

Walter, Tony. "New Mourners, Old Mourners: Online Memorial Culture as a Chapter in the History of Mourning." New Review of Hypermedia and Multimedia 21.1-2 (2015): 10-24.

Wagner, Anna. "Do not Click "Like" When Somebody has Died: The Role of Norms for Mourning Practices in Social Media". Social Media + Society 4.1. (2018): 1-11.

Walter, Tony. What Death Means Now: Thinking Critically about Death and Grieving. University of Bristol: Polity Press, 2017.

\section{ABOUT THE AUTHOR}

Korina Giaxoglou is lecturer in English Language and Applied Linguistics at The Open University, UK. Her research lies at the intersection of linguistic anthropology, the sociolinguistics of narrative, and (mediated) discourse analysis. Her work has appeared in peer-reviewed journals, including Applied Linguistics Review; Discourse, Context, $\mathcal{E}$ Media; and the New Review of Hypermedia and Multimedia. The publication of her research monograph on Sharing small stories of mourning online by Routledge is forthcoming. Email: korina.giaxoglou@open.ac.uk 


\section{NOTES}

1 The notion of 'entextualisation' is part of Bauman \& Briggs' (1990) proposed framework of critical poetics that draws attention to the study of contextualized histories of performance and their role in social life.

2 See Thompson, R. (2017) A guide to Facebook etiquette after someone has died. Mashable UK [online]. Available at: http://mashable.com/2017/04/08/facebook-etiquettegrief/\#i7QJZcTq6Pqr. Accessed: February 182018.

3 See Wickman, F. (2014). The Rules of Twitter Grief. Ten lessons about micro-mourning without antagonizing your followers. Slate [Online]. Available at: http://www.slate.com/ articles/life/culturebox/2014/08/mourning_on_social_media_10_rules_of_twitter_ grief.html. Accessed: February 182018.

4 According to Pew Research Centre (2018), around seven in ten members of the population use social media to connect with one another, engage with news content, share information and entertain themselves on a daily basis. (see Pew Research Centre. Social Media Fact Sheet. Available at: http://www.pewinternet.org/fact-sheet/social-media/. Accessed 18 February 2018).

5 MyDeathSpace (MyDeathSpace.com) was created in 2005 by 25-year old Mike Patterson who linked the profiles of deceased MySpace users with their obituaries, enabling a discussion forum for talking about the deaths. For friends and relatives the site ended up serving as a memorial to those who have died (ABC, 2006; available at: http://abcnews. go.com/Technology/story?id=2384990.

6 MySpace is a social networking site created in 2003. It offered for the first time the possibility of a new kind of shared experience for millions of users connected by their interest in music and popular culture.

7 See https://www.facebook.com/MyDeathSpace/.

8 [sic] Posts are reproduced as they appear.

9 The bold typeface has been added by the author to highlight selected parts of the posts.

10 The phrase "I am/We are X" resonates strongly with the iconic statement 'I am Spartacus' uttered by Spartacus' friends as a symbol of defiance and solidarity in Stanley Kubrick's film Spartacus (1960), before featuring in the editorial of Le Monde in the wake of 9/11 attacks as an international symbol of solidarity ("Nous sommes tous Americains"/"We are all Americans") and turning into a potent political strategy (Occupy protesters holding up signs reading 'I am the 99\%'; social media users reacting to the tragic death of 3 year old Syrian boy by using the hashtag 'I am Aylan').

11 Posts are cited in the reverse chronological order, as they appear on the memorial wall.

12 https://www.theguardian.com/commentisfree/2018/jul/25/mark-zuckerberg-facebook-sandy-hook-parents-open-letter.

13 Available at: https://mashable.com/2018/02/15/russian-bots-twitter-florida-shooting/ ? europe $=$ true. 